\title{
Measuring Progress Towards Sustainability: the Geographer's view
}

\author{
Katja Vintar Mally
}

\begin{abstract}
Measuring progress towards sustainability goals is of key importance for successful policy-making. Numerous initiatives worldwide propose diverse sets of sustainable development indicators, monitoring changes in individual economic, social, and environmental aspects of development. On the other hand, there is still no consensus on the best composite indicator, which would encompass those aspects and allow comparisons across countries. The paper evaluates the suitability of some composite indicators (green GDP initiatives, Environmental Performance Index, Ecological Footprint, Human Development Index, Happy Planet Index) for sustainability measurement and also proposes an alternative measure of overall development - the Development Balance Index - in an attempt to bring to a common denominator a country's socio-economic achievements as well as their accompanying environmental pressures.
\end{abstract} Index

Key words: sustainable development, development indicators, Development Balance

\section{Mjerenje napretka prema održivosti: geografski pogled}

Mjerenje napretka prema ciljevima održivosti od ključne je važnosti za uspješno upravljanje. Brojne inicijative u svijetu predlažu čitav niz indikatora održivog razvoja koji prate promjene $\mathrm{u}$ individualnim ekonomskim, društvenim i okolišnim aspektima razvoja. S druge strane, ne postoji konsenzus oko najboljega složenog indikatora koji bi obuhvatio sve te aspekte i omogućio usporedbu država. Ovaj rad vrednuje pogodnost nekih složenih indikatora (inicijativa Zeleni BDP, Indeks provedbe zaštite okoliša EPI, Ekološki otisak, Indeks razvijenosti ljudskog potencijala HDI te Indeks sretnog planeta HPI) u mjerenju održivosti te predlaže alternativnu mjeru ukupnog razvoja - Indeks bilance razvoja DBI u nastojanju da se socioekonomska postignuća zemalja i njihovi okolišni problemi svedu pod isti nazivnik.

Ključne riječi: održivi razvoj, indikatori razvoja, Indeks uravnoteženog razvoja 


\section{INTRODUCTION}

Numerous contemporary geographical research projects are focusing on the interactions between human society and the environment. Geography as a complex scientific discipline has a lot to offer to the understanding of sustainable development as an overarching developmental paradigm. Its implementation requires a profound understanding of natural environment (as traditionally studied by physical geography) on the one hand and an extensive knowledge about human activities and interactions (as traditionally studied by human geography) on the other. The basic requirement of the sustainable development concept refers to the adapting of human activities to the carrying capacities of the environment. In order to achieve this, that is, to decouple environmental degradation and resource consumption from socio-economic development, all the available geographical knowledge has to be combined.

In the past two decades, many researchers (among them also geographers) focused their work on measuring and monitoring the progress made in general, and especially from the perspective of sustainability goals achieving. As a result, several hundred sustainable development indicator initiatives have been proposed worldwide (see for example, Compendium: a global directory to indicator initiatives, 2010). The purpose of the following discussion is not to elaborate on the definition of the sustainable development but rather to evaluate the most renowned approaches to its measurement and to propose some new solutions.

\section{THEORETICAL AND METHODOLOGICAL FRAMEWORK}

New development paradigms call for new approaches to progress measurement. Undoubtedly, sustainable development has become an overarching objective of the European Union and other countries around the world in the last two decades. In the European Union, unsustainable trends in the past years have contributed to the decision on issuing a more ambitious and renewed sustainable development strategy in 2006 (Renewed EU Sustainable ..., 2006), which added the third (environmental) dimension to the Lisbon strategy of economic and social renewal. In December 2009, the European Council confirmed that sustainable development remains a fundamental objective of the EU also under the Lisbon Treaty (Brussels European Council ..., 2009). The new Europe 2020 strategy highlights three mutually reinforcing priorities: smart growth (based on knowledge and innovation), inclusive growth (high-employment, social and territorial cohesion), and sustainable growth. The latter should promote a more resource efficient, greener and more competitive economy (Europe ..., 2010, p. 3). Following the commitments of the 1992 UN Conference on Environment and Development in Rio de Janeiro and obligations of Agenda 21, individual EU member states and other European countries have since 1990s adopted their own national sustainable development strategies. The majority of these strategies also includes sustainable development indicators as key elements of the whole strategic progress (for details, see European Sustainable Development Network, 2010).

Implementation of sustainable development strategies requires constant monitoring of the progress made and also developing of suitable indicators. Indicators of sustainable development serve as tools for translating the concept into practical terms, defining concrete 
development goals and measures, and as an orientation for making political decisions and evaluating the progress of achieving the goals (Vintar Mally, 2009a). Every two years, the European Commission issues a special progress report on the implementation of the EU sustainable development strategy (Mainstreaming sustainable development ..., 2009), complemented by Eurostat's monitoring report (Sustainable development in the European Union ..., 2009), which covers more than 100 sustainable development indicators. Individual European countries are also reviewing their experiences and tracking progress on sustainability goals. These reports form the basis for discussion and are useful in guiding further political decisions. However, the messages are mixed due to the usually high number of indicators included, some of them showing favourable trends, others quite the opposite. The same applies to the majority of contemporary sustainability research,projects, which use numerous quantitative and sometimes also qualitative indicators with the ambition of encompassing "all" relevant sustainability issues.

Through our research we have studied many individual and composite indicators that are widely used to track progress on one or more sustainability dimensions: economic, social or environmental. In the paper we evaluate only some selected composite indicators that are the most prominent in their field: green GDP initiatives, Environmental Performance Index, Ecological Footprint, Human Development Index, and Happy Planet Index. Considering the great need for composite indicators that summarize important economic, social, and environmental issues with a single figure, we propose the use of Development Balance Index, an alternative index with the ambition of measuring the level of general balance in all three development areas. In the statistical analysis we have used the available data for all countries of the world, whereas in the article we present mainly data for forty European countries.

\section{SUSTAINABLE DEVELOPMENT INDICATOR INITIATIVES}

For decades, progress has been measured by Gross Domestic Product (GDP) although GDP is merely a measure of macro-economic activity. Nowadays, experts as well as public opinion support the equal use of different progress indicators. According to 2008 Eurobarometer poll more than two thirds of EU citizens feel that social, environmental, and economic indicators should be used equally to evaluate progress. On the other hand, less than one sixth of the asked citizens prefer evaluation based mostly on economic indicators (GDP and beyond ..., 2009). Therefore, the European Commission supports the development of improved indicators in order to measure better the progress and the well-being of nations.

Due to the extensive tradition and methodological experiences it would be most convenient to adjust the GDP in such a manner that it would incorporate the missing economic, social, and environmental issues. The critiques of GDP usually relate to its insensitivity to income distribution, inability to distinguish good from bad expenditures (for example, expenditures on medicine or arms) and productive activities from destructive ones. GDP does not internalize the costs of environmental damage, moreover it treats depletion of stocks of natural capital as income (Thompson et al., 2007; Talberth, 2007). There have been several attempts to address these deficiencies and to "green" the GDP. The Index of 
Sustainable Economic Welfare (ISEW) and the Genuine Progress Indicator (GPI) are just two of the most prominent green GDP accounting systems, which take account of the value of unpaid and volunteer work as well as the costs of inequality, environmental degradation and pollution, crime and accidents, etc. (Talberth, 2007). Unfortunately, the indices are still developing and no comparable worldwide national calculations are available. However, the results of existing case studies are worrying. In the last decades, GDP per capita has risen constantly, while GPI has stagnated since the 1970s. This is yet another warning of the huge social and economic costs of the economic growth.

The second direction in sustainability progress monitoring is represented by numerous attempts to create aggregate measures of different aspects of sustainability, especially environmental ones. Two of the most prominent environmental indices, each covering more than 20 environmental indicators, are the Environmental Sustainability Index (ESI) and the Environmental Performance Index (EPI) (see for example, 2005 Environmental Sustainability Index, 2005; 2010 Environmental Performance Index, 2010). The development work on ESI halted and the authors of the last EPI report recently proclaimed it as essential to the EPI calculation. The EPI measures the effectiveness of national environmental protection efforts in 163 countries worldwide and relies on 25 indicators for ten policy categories (Tab. 1). Scores are calculated at three levels of aggregation: (i) for each of ten core policy categories based on one to four underlying indicators, (ii) for the objective of environmental health (measuring environmental stresses to human health) and ecosystem vitality (measuring ecosystem health and natural resource management), and (iii) for the overall Environmental Performance Index (2010 Environmental Performance Index, 2010). Different weight is assigned to the individual indicators and the selection of indicators is limited by the lack of data quality and availability. The EPI 2010 scores range between 93.5 (Iceland) and 32.1 (Sierra Leone). Iceland ranked highest (93.5) and was followed by Switzerland (89.1), Costa Rica (86.4), Sweden (86.0), and Norway (81.1) (Table 2). Economically developed countries are usually higher on a rank list (for example, more than half of the 30 best ranked countries are European countries), whereas many Sub-Saharan African countries have weak policy capacity and lack resources for health care or investments in basic infrastructure and environment (2010 Environmental Performance Index, 2010). The EPI primarily evaluates the progress towards the preset targets for environmental performance. However, it does not give the information about the extent of the countries total environmental pressures. In this regard, Ecological Footprint still leads the way.

The Ecological Footprint concept was initially developed in 1990s by Mathis Wackernagel and his colleagues (see Rees, 1992; Wackernagel and Rees, 1996). Every two years new calculations are published by Global Footprint Network and World Wildlife Fund. Ecological Footprint measures the extent to which individual countries are using global natural resources, especially when compared to the biocapacity (as a kind of carrying capacity) of their own and global ecosystems (Living Planet ..., 2006; Moran et al., 2008). Ecological Footprint calculates biologically productive land and water area required to produce all the resources consumed and to absorb the waste generated. Consequently, it is expressed in global hectares (gha) per capita (which are hectares with world-average biological capacity). The Ecological Footprint measures appropriated biocapacity across 
Tab. 1 Environmental Performance Index Framework - objectives, policy categories, and indicators Tab. 1. Indeks provedbe zaštite okoliša EPI-ciljevi, kategorije i indikatori

\begin{tabular}{|c|c|c|}
\hline Objectives & Policy Categories & Indicators \\
\hline \multirow{5}{*}{$\begin{array}{c}\text { Environmental } \\
\text { Health }\end{array}$} & Environmental Burden of Disease & Environmental Burden of Disease \\
\hline & \multirow{2}{*}{ Water (effects on humans) } & Access to Drinking Water \\
\hline & & Access to Sanitation \\
\hline & \multirow{2}{*}{ Air Pollution (effects on humans) } & Urban Particulates \\
\hline & & Indoor Air Pollution \\
\hline \multirow{20}{*}{$\begin{array}{l}\text { Ecosystem } \\
\text { Vitality }\end{array}$} & \multirow{4}{*}{$\begin{array}{l}\text { Air Pollution (effects on ecosy- } \\
\text { stems) }\end{array}$} & Sulphur Dioxide Emissions \\
\hline & & Nitrogen Oxide Emissions \\
\hline & & Volatile Organic Compound Emissions \\
\hline & & Ozone Exceedance \\
\hline & \multirow{3}{*}{ Water (effects on ecosystems) } & Water Quality Index \\
\hline & & Water Stress \\
\hline & & Water Scarcity Index \\
\hline & \multirow{3}{*}{ Biodiversity and Habitat } & Biome Protection \\
\hline & & Critical Habitat Protection \\
\hline & & Marine Protected Areas \\
\hline & \multirow{2}{*}{ Forestry } & Growing Stock \\
\hline & & Forest Cover \\
\hline & \multirow{2}{*}{ Fisheries } & Marine Trophic Index \\
\hline & & Trawling Intensity \\
\hline & \multirow{3}{*}{ Agriculture } & Pesticide Regulation \\
\hline & & Agricultural Water Intensity \\
\hline & & Agricultural Subsidies \\
\hline & \multirow{3}{*}{ Climate Change } & Greenhouse Gas Emissions / Capita \\
\hline & & Electricity Carbon Intensity \\
\hline & & Industrial Carbon Intensity \\
\hline
\end{tabular}

Source: 2010 Environmental Performance Index, 2010, 12.

Izvor: Indeks provedbe zaštite okoliša EPI, 2010.

five different land use types (i.e., built-up land, forest land, fishing ground, grazing land, and cropland) and the demand on carbon uptake land (i.e., carbon footprint) (Living Planet ..., 2008; detailed methodological explanations available at Global Footprint Network, 2011). The national Ecological Footprint encompasses the natural resources and the ecological services that usually originate from all over the world and are being consumed in the country, while the exports are subtracted. This composite indicator is constantly being methodologically upgraded and its calculations still fail to capture some significant aspects of resource consumption and waste generation (for example, the land use intensity, freshwater withdrawals, heavy metals, radioactive compounds, etc.), but nonetheless it is currently the most synthetic evaluation of total environmental pressures.

In 2006, the global Ecological Footprint was 17.1 billion gha (2.6 gha per capita), while there were only 11.9 billion gha of biocapacity available ( 1.8 gha per capita). These data show that humanity's demand on nature exceeds the planet's ability to provide 
biological resources by more than 40 percent. In 1961, humanity's Footprint was about half of the Earths' biocapacity. In the next two decades, around 1980, the Ecological Footprint already exceeded global biocapacity. European countries have on average 3.0 gha of biocapacity per person, while the Ecological Footprint amounts to 4.5 gha per person (Tab. 2), clearly showing the unsustainable development patterns. Moldova (1.7 gha per capita) has the lowest Ecological Footprint in Europe while the highest belongs to Ireland (8.2 gha per capita). Worldwide, the highest Ecological Footprints per capita are found in the United Arab Emirates (10.3 gha per capita), Qatar (9.7 gha per capita), and in the United States of America (9.0 gha per capita). On the other hand, the lowest average demand on biosphere is in Africa (1.4 gha per capita). Some ecological reserve (i.e., the biocapacity of a country's territory is still higher than its Ecological Footprint of consumption) is evident in 57 of 149 countries, among them in seven European countries (Sweden, Finland, Latvia, Estonia, Norway, Russia, and Lithuania) (Ewing et al., 2009). All other European countries are relying on natural resources and ecological services from other parts of the world in order to sustain the current wasteful way of life. If everyone in the world lived the lifestyle of an average resident of Europe, we would need the biocapacity of 2.5 Earths. Further statistical analysis of the relation between socio-economic indicators (GDP and Human Development Index) and total environmental pressures (as expressed in the Ecological Footprint) confirm the assumption that the higher the standard of living, the higher the accompanying environmental pressures. The correlation between the Ecological Footprint and the GDP per capita as well as the correlation between the Ecological Footprint and the HDI in 2006 is positive and large. The Pearson correlation coefficient reaches 0.834 in the first case and 0.729 in the second case (with correlation being significant at the 0.01 level). The actual correlation between the Ecological Footprint and GDP per capita is probably even larger due to the fact that both variables have a skew in the opposite direction. In both cases, the calculations are based on 145 countries with adequate data. The analysis confirms that growing economic activity is still one of the most important driving forces behind environmental pressures. The correlations between social indicators and the Ecological Footprint strongly suggest that social progress has similarly important and direct effects on the extent of environmental pressures.

The search for good composite indicators is not limited only to the environmental dimension of the sustainability. Besides the initiatives to improve the GDP accounting system, there have been several attempts to combine GDP with other welfare measures in order to produce better socio-economic indicators. The most widely-known is the Human Development Index, developed by the UN in 1990s and yearly published in the so-called Human Development Report by the United Nations Development Programme.

The Human Development Index (HDI) is based on the assumption that the GDP growth does not translate directly into improved human well-being. Economic growth can boost human development if it enhances knowledge and skills, provides opportunities for their efficient use, including better job opportunities, and supports greater democracy (Gaye 2007, 264). The HDI focuses on its three measurable dimensions: (i) living a long and healthy life (as measured by life expectancy at birth), (ii) being educated (as measured by the adult literacy rate and the combined primary, secondary, and tertiary enrolment ratio), and (iii) having a decent standard of living (as measured by GDP per capita in 
purchasing power parity terms) (Human Development ..., 2009). Over the years the index has experienced many methodological improvements, the last one in 2010. The concept of human development is much broader, whereas the index fails to include aspects of political freedom, social safety and justice, the quality of the living environment, etc. Trends over time show a gradual increase in HDI values. Due to the standardization method, the index values are between zero and one. According to UNDP calculations, the values of the HDI in 2006 ranged from 0.970 (Norway) to 0.335 (Niger). In European countries the values were between 0.970 (Norway) and 0.718 (Moldova). The majority of European countries are relatively successful in achieving a high level of human development (with HDI above 0.800 ) (Table 2). Although the so-called transition countries experienced a drop in the HDI in the $1990 \mathrm{~s}$, their indices improved in the $21^{\text {st }}$ century. In comparison to countries with similar incomes from other world regions, they demonstrate better health and education opportunities. In general, the HDI reveals huge socio-economic disparities among world countries and regions. The majority of African countries (with the exception of Libya, the Seychelles, Tunisia, Gabon, and Algeria) remains below the world average, and 24 countries of the world are below the middle human development threshold (0.500): 23 Sub-Saharan countries and Afghanistan are lagging behind other countries mostly in all aspects of human development.

Since the 1990s, there have been some statistical attempts to include environmental issues into the HDI calculation with limited success (see for example, Atkinson and Hamilton, 1996; Constantini and Monni, 2005). Especially meaningful are the comparisons of the HDI and the Ecological Footprint. If the minimum criteria for sustainability are set at the Ecological Footprint of 1.8 gha per capita or even lower (which is the average biocapacity available per person on the planet) and at the HDI of 0.800 or even higher (which is the threshold for high human development), no country in the world meets both criteria. Developed countries with high incomes easily exceed the high human development threshold and at the same time use a lot more than their fair share of global biocapacity. On the contrary, low income developing countries use less than 1.8 gha per capita and have great difficulties at providing higher levels of human development. Moreover, the analysis confirms that developing countries are also failing to decouple economic growth from resource consumption and are following the unfavourable example of high income countries (Vintar Mally, 2009 b).

The calculation of the Happy Planet Index (HPI), launched in 2006 by the New economics foundation is also based on the input-output rationale presented above. The HPI combines experienced well-being (as measured by happy life years, which is a result of life expectancy and life satisfaction multiplied together) and resource consumption (as measured by Ecological Footprint) (Abdallah et al., 2009). It actually measures the efficiency of providing well-being per unit of resource consumption (Thompson et al., 2007, 276). The primary goal is to maximize well-being and minimize the Ecological Footprint. A country achieving maximum life satisfaction (10) and life expectancy of 85 years, while living within its global fair share of natural resources, would score 100. Results in 2005 (Abdallah et al., 2009) show the highest HPI score in Costa Rica (76.1), followed by the Dominican Republic, Jamaica, Guatemala, Vietnam, Colombia, Cuba, etc. In general, Latin American and Caribbean nations have the highest mean HPI of any region (59.0), 
Tab. 2 Key composite indicators of European countries

Tab. 2. Glavni složeni indikatori europskih zemalja

\begin{tabular}{|c|c|c|c|c|c|c|c|c|c|c|}
\hline \multirow[b]{2}{*}{ Country } & \multicolumn{2}{|c|}{ EPI* $^{*}$} & \multicolumn{2}{|c|}{$\begin{array}{c}\mathrm{EF}^{* *} \\
2006\end{array}$} & \multicolumn{2}{|c|}{$\begin{array}{l}\mathrm{HDI}^{* * * *} \\
2006\end{array}$} & \multicolumn{2}{|c|}{$\begin{array}{c}\mathrm{HPI}^{* * * *} \\
2005\end{array}$} & \multicolumn{2}{|c|}{$\begin{array}{l}\mathrm{DBI}^{* * * * *} \\
2006\end{array}$} \\
\hline & $\frac{⿱ 亠 凶}{.0}$ & 華 & 离. & है & $\frac{\varpi}{0}$ & 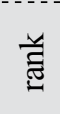 & $\frac{\varpi}{0}$ & 芸 & 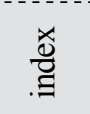 & 莽 \\
\hline Albania & 71.4 & 23 & 2.6 & 68 & 0.814 & 70 & 47.9 & 54 & 0.771 & 48 \\
\hline Austria & 78.1 & 8 & 4.9 & 24 & 0.952 & 15 & 47.7 & 57 & 0.810 & 12 \\
\hline Belarus & 65.4 & 53 & 4.2 & 34 & 0.819 & 69 & 35.7 & 104 & 0.731 & 70 \\
\hline Belgium & 58.1 & 88 & 5.7 & 17 & 0.951 & 17 & 45.4 & 64 & 0.781 & 41 \\
\hline Bosnia-Herzegovina & 55.9 & 98 & 3.4 & 46 & 0.807 & 76 & 45.0 & 65 & 0.743 & 68 \\
\hline Bulgaria & 62.5 & 65 & 3.3 & 48 & 0.835 & 59 & 42.0 & 82 & 0.770 & 50 \\
\hline Croatia & 68.7 & 35 & 3.3 & 48 & 0.867 & 45 & 47.2 & 60 & 0.796 & 20 \\
\hline Cyprus & 56.3 & 96 & 7.7 & 6 & 0.911 & 32 & 46.2 & 62 & 0.685 & 97 \\
\hline Czech Republic & 71.6 & 22 & 5.3 & 23 & 0.899 & 35 & 38.3 & 92 & 0.757 & 59 \\
\hline Denmark & 69.2 & 32 & 7.2 & 8 & 0.953 & 14 & 35.5 & 105 & 0.733 & 69 \\
\hline Estonia & 63.8 & 57 & 6.4 & 12 & 0.878 & 40 & 36.4 & 131 & 0.705 & 85 \\
\hline Finland & 74.7 & 12 & 5.5 & 21 & 0.955 & 13 & 47.2 & 59 & 0.789 & 29 \\
\hline France & 78.2 & 7 & 4.6 & 27 & 0.958 & 10 & 43.9 & 71 & 0.821 & 9 \\
\hline Germany & 73.2 & 17 & 4.3 & 37 & 0.945 & 21 & 48.1 & 51 & 0.834 & 5 \\
\hline Greece & 60.9 & 71 & 5.8 & 16 & 0.938 & 25 & 37.6 & 97 & 0.766 & 51 \\
\hline Hungary & 69.1 & 33 & 3.2 & 52 & 0.878 & 40 & 38.9 & 90 & 0.811 & 11 \\
\hline Iceland & 93.5 & 1 & $\ldots$ & $\ldots$ & 0.967 & 3 & 38.1 & 94 & $\ldots$ & $\ldots$ \\
\hline Ireland & 67.1 & 44 & 8.2 & 4 & 0.964 & 5 & 42.6 & 78 & 0.708 & 84 \\
\hline Italy & 73.1 & 18 & 4.9 & 24 & 0.950 & 18 & 44.0 & 69 & 0.804 & 14 \\
\hline Latvia & 72.5 & 21 & 4.6 & 27 & 0.859 & 50 & 36.7 & 101 & 0.748 & 65 \\
\hline Lithuania & 68.3 & 37 & 3.3 & 48 & 0.865 & 46 & 40.9 & 86 & 0.797 & 18 \\
\hline Luxembourg & 67.8 & 41 & $\ldots$ & $\ldots$ & 0.959 & 8 & 28.5 & 122 & $\ldots$ & $\ldots$ \\
\hline Macedonia & 60.6 & 73 & $\ldots$ & $\ldots$ & 0.813 & 72 & 32.7 & 111 & $\ldots$ & $\ldots$ \\
\hline Malta & 76.3 & 11 & 6.2 & 13 & 0.899 & 35 & 50.4 & 44 & 0.727 & 73 \\
\hline Moldova & 58.8 & 86 & 1.7 & 90 & 0.718 & 117 & $\ldots$ & $\ldots$ & 0.725 & 74 \\
\hline Montenegro & 69.4 & $29^{1}$ & $\ldots$ & $\ldots$ & 0.828 & 65 & $\ldots$ & $\ldots$ & $\ldots$ & $\ldots$ \\
\hline Netherlands & 66.4 & 47 & 4.6 & 27 & 0.961 & 6 & 50.6 & 43 & 0.826 & 7 \\
\hline Norway & 81.1 & 5 & 4.2 & 34 & 0.970 & 1 & 40.4 & 88 & 0.845 & 3 \\
\hline Poland & 63.1 & 63 & 3.9 & 38 & 0.876 & 42 & 42.8 & 77 & 0.781 & 42 \\
\hline Portugal & 73.0 & 19 & 4.4 & 31 & 0.907 & 33 & 37.5 & 98 & 0.790 & 27 \\
\hline Romania & 67.0 & 45 & 2.7 & 64 & 0.832 & 63 & 43.9 & 70 & 0.792 & 25 \\
\hline Russia & 61.2 & 69 & 4.4 & 31 & 0.811 & 73 & 34.5 & 108 & 0.729 & 72 \\
\hline Serbia & 69.4 & $29^{1}$ & $\ldots$ & $\ldots$ & 0.821 & 67 & 47.6 & 58 & $\ldots$ & $\ldots$ \\
\hline Slovakia & 74.5 & 13 & 4.9 & 24 & 0.873 & 44 & 43.5 & 73 & 0.752 & 62 \\
\hline Slovenia & 65.0 & 55 & 3.9 & 38 & 0.924 & 29 & 44.5 & 66 & 0.819 & 10 \\
\hline Spain & 70.6 & 25 & 5.6 & 18 & 0.952 & 15 & 43.2 & 76 & 0.782 & 40 \\
\hline Sweden & 86.0 & 4 & 2.8 & 61 & 0.961 & 6 & 48.0 & 53 & 0.884 & 1 \\
\hline Switzerland & 89.1 & 2 & 5.6 & 18 & 0.959 & 8 & 48.1 & 52 & 0.793 & 21 \\
\hline Ukraine & 58.2 & 87 & 2.7 & 64 & 0.789 & 84 & 38.1 & 95 & 0.754 & 61 \\
\hline United Kingdom & 74.2 & 14 & 6.1 & 14 & 0.945 & 21 & 43.3 & 74 & 0.765 & 53 \\
\hline
\end{tabular}




\begin{abstract}
* Environmental Performance Index - data and calculations available for 163 countries of the world;
** Ecological Footprint - data and calculations available for 149 countries of the world; *** Human Development Index - data and calculations available for 182 countries of the world; **** Happy Planet Index - data and calculations available for 143 countries of the world; *****Development Balance Index data and calculations available for 145 countries of the world; "..." data not available; 1 - data for Serbia and Montenegro together

* Indeks provedbe zaštite okoliša EPI-podaci i izračun dostupni za 163 države; ** Ekološki otisak-podaci i izračun dostupni za 149 država; *** Indeks razvijenosti ljudskog potencijala HDI-podaci i izračun dostupni za 182 države; **** Indeks sretnog planeta HPI-podaci i izračun dostupni za 143 države; ***** Indeks uravnoteženog razvoja - podaci i izračun dostupni za 145 država ; ,... ” podaci nedostupni; 1 podaci za Srbiju i Crnu Goru zajedno
\end{abstract}

Sources: Abdallah et al., 2009 (for Happy Planet Index); Ewing et al., 2009 (for Ecological Footprint); 2010 Environmental Performance Index, 2010 (for Environmental Performance Index), UNDP, 2010 (for Human Development Index); author's calculations (for Development Balance Index).

Izvori: Abdallah et al., 2009 (za Indeks sretnog planeta); Ewing et al., 2009 (za Ekološki otisak); 2010 Environmental Performance Index, 2010 (za Indeks provedbe zaštite okoliša), UNDP, 2010 (za Indeks razvijenosti ljudskog potencijala); izračun autora (za Indeks uravnoteženog razvoja).

while the bottom ten scores are those of Sub-Saharan African countries (Zimbabwe ranked last with 16.6). Some European and other countries in the West achieve good well-being outcomes at very high environmental costs. The highest placed European countries are The Netherlands (with 50.6 ranked $43^{\text {rd }}$ ), Malta, Germany, Switzerland, Sweden, Albania, Austria, Serbia, Finland, Croatia, etc. (Tab. 2). The HPI results confirm that people enjoy the happiest and healthiest lives mostly in wealthier countries with higher environmental pressures, however, there are also many exceptions, where people experience a high level of well-being with considerably smaller Ecological Footprints per capita. Despite its creative approach, the HPI is still limited by many methodological deficiencies and is mostly being criticized for its unsuitable name (as presented above, it is not a measure of happiness), substantial data gaps and for including subjective measures of well-being.

\title{
DEVELOPMENT BALANCE INDEX
}

If human welfare is being achieved at the expense of environmental deterioration, the measurement of development achievements should include not only economic and social benefits but also their environmental costs. From the sustainability perspective as well as from the geographical point of view, those issues are inseparable. To this end, we have developed a new alternative measure of overall progress - the Development Balance Index (DBI). The key idea is to combine the best socio-economic and environmental composite indicators: the Human Development Index and the Ecological Footprint. The DBI uses the same standardization as proposed by UNDP for the calculation of human development indices:

$$
\text { index }=\frac{\mathrm{x}_{\mathrm{i}}-\mathrm{x}_{\min }}{\mathrm{x}_{\max }-\mathrm{x}_{\min }}
$$

The HDI is actually a simple average of three dimension indices: life expectancy index, education index, and GDP index. In order to calculate the performance in each dimension, 
minimum and maximum values or goalposts are chosen for every underlying indicator. The scores for each dimension index and the final HDI are a value between zero and one. For example, in 2006, the dimension indices for Slovenia amounted to: life expectancy 0.881; GDP index - 0.923; education index -0.969 . Therefore, its HDI reached 0.924 (= $1 / 3$ (GDP index + education index + life expectancy index $)$ ).

In order to incorporate the calculations of the Ecological Footprint into this scheme, the standardization formula has to be adjusted. In contrast to longevity, education, and incomes, increasing values of the Ecological Footprint or increasing environmental pressures respectively, do not contribute to overall welfare or sustainability. Therefore, the result according to the usual standardization formula has to be subtracted from the maximum value of 1 to produce the ecological footprint index. For the calculation of the ecological footprint index, the maximum value of 10.0 gha per capita and the minimum value of 0.0 gha per capita were used (for additional methodological explanations, see Vintar Mally, 2009a, 2009b). Finally, all indices (GDP index, education index, life expectancy index, and ecological footprint index) can be added up and an average value - the Development Balance Index - for each country can be calculated. The DBI does not only upgrade the HDI by the environmental dimension, but the two indices differ also in the weight assigned to particular dimensions involved. The HDI is actually the uniformly weighted sum with one-third contributed by the GDP index, one-third by the education index, and one-third by the life expectancy index. Consequently, the economic dimension has one-third weight and the social dimension together has two-thirds weight. However, the DBI gives an equal (one-third) weight to common achievements in the economic (GDP index), social (education index and life expectancy index together), and environmental area (ecological footprint index). From the sustainability viewpoint, the DBI is more appropriate as it requires an equal emphasis on all three areas of development in order to achieve ongoing balanced development:

Development Balance Index $=1 / 3($ GDP index $+1 / 2$ (education index + life expectancy index) + ecological footprint index)

In the above presented case of Slovenia with the Ecological Footprint of 3.9 gha per capita (2006), the DBI reached $0.819(=1 / 3(0.923+1 / 2(0.969+0.881)+0.610)$.

The presented alternative index attempts to evaluate the level of general balance of development in each country or/and region. In comparison to usual development measures (such as GDP per capita or HDI) the calculations of DBI reveal a different image of general well-being and development in the world and European countries. Comparing the scores of 145 countries, it becomes obvious that the inclusion of environmental pressures considerably changes the world's ranking list. Due to their disproportionately high demand on the biosphere many high income countries rank considerably worse than according to the HDI. The most favourable balance of social, economic, and environmental development is observed in Sweden (0.884), Brunei (0.853), Norway (0.845), Japan (0.837), and Germany (0.834). On the other hand, some developing countries with a relatively low Ecological Footprint and good education or health performance, are keeping pace with the best ranked developed countries, such as Venezuela (with 0.805 ranked $13^{\text {th }}$ ), followed by Chile, Cuba, Argentina, Costa Rica, etc. 


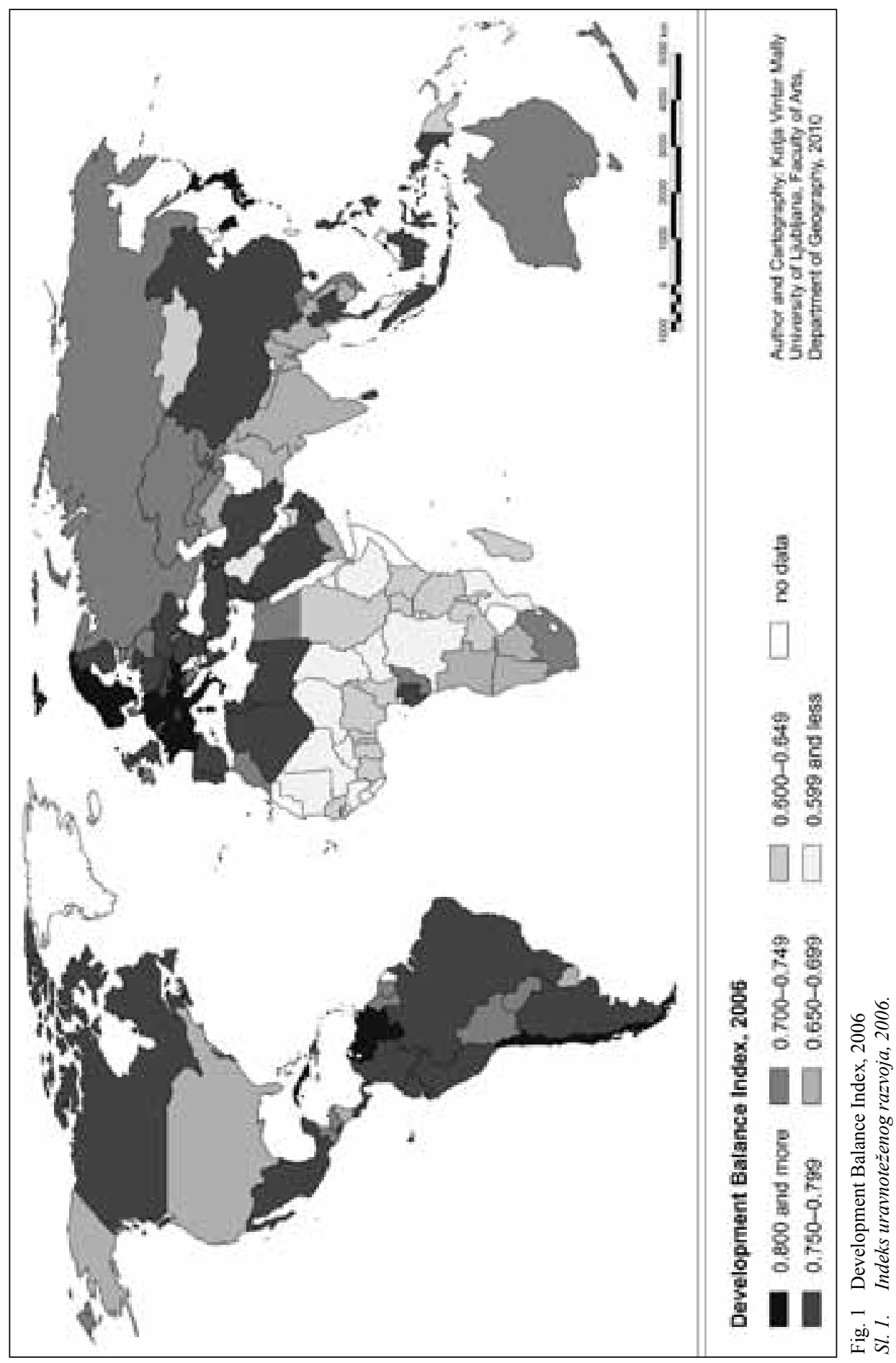


The calculation method of the DBI, especially the standardization with preset minimum and maximum values, allows the results to be compared over time and across countries. Every composite measure suffers from the same deficiencies as indices included in its calculation and the same applies also to our index. Therefore, the DBI fails to include issues of political freedom, social safety and justice, some aspects of resource consumption and waste generation, and some other important factors, which affect the quality of our everyday life. Although it is currently not possible to include these aspects into the calculation, the methodological approach enables further improvements at any point in the future.

\section{CONCLUSIONS}

A number of development indicators and studies are leading to the same conclusion. Current global development patterns are not only unsustainable but also unjust, especially from the viewpoint of developing countries, economically excluded groups, and future generations with no influence on current development choices. The consumption of natural resources and ecological services in developed countries is disproportionately high and causes numerous environmental and social problems worldwide. Although many developing countries still use less than their fair share of the planet's ecosystem services, their socioeconomic welfare is also being achieved at the expense of environmental deterioration. Additionally, they also have difficulties in providing higher levels of human development.

In general, the questions of balanced social, economic, and environmental development at different spatial levels worldwide are probably the greatest professional challenge for geographers in the $21^{\text {st }}$ century. We should participate at providing clear and politically strong messages to facilitate development towards sustainability. In this regard, composite development measures are of great value and use, especially when encompassing all three sustainability dimensions. The Development Balance Index provides one such example, upgrading the Human Development Index by Ecological Footprint in an attempt to bring to a common denominator a country's socio-economic achievements as well as their accompanying environmental pressures. It raises awareness about the complexity of development issues and stimulates further work on sustainability indicators.

While measuring overall progress is of great importance, some global solutions to the above mentioned problems are nevertheless quite obvious: green tax policies, a sustainable world trading system, transition to the use of renewable energy technologies, improvements in resource use efficiency, phase-out of environmentally damaging subsidies, transfer of technologies to developing countries, etc. However, with the profound understanding of interactions between human society and the environment, geographical knowledge is probably most appreciated and needed at the local level. The most challenging research topics are those referring to the adaptation of human activities to the environment's carrying capacities, such as management of various natural resources, sustainable production and consumption, demographic changes, standard of living, social equity and cohesion, sustainable transport and some other locally important sustainability issues with global implications. 


\section{REFERENCES}

Abdallah, S., Thompson, S., Michaelson, J., Marks, N., Steuer, N., 2009: The Happy Planet Index 2.0, New Economics Foundation, London.

Atkinson, G., Hamilton, K., 1996: Accounting for progress: indicators for sustainable development, Environment 38 (7), 16-20 and 40-44.

Brussels European Council Conclusions - 10/11 December - Presidency conclusions, European Council, Brussels, 2009.

Constantini, V., Monni, S., 2005: Sustainable Human Development for European Countries, Journal of Human Development and Capabilities 6 (3), 329-351.

Compendium: a global directory to indicator initiatives, International Institute for Sustainable Development, http://www.iisd.org/measure/compendium (15.12.2010).

2010 Environmental Performance Index, Yale Center for Environmental Law and Policy, Center for International Earth Science Information-Network, Columbia University, 2010.

2005 Environmental Sustainability Index, Yale Center for Environmental Law and Policy, New Haven, 2005.

Europe 2020: a European strategy for smart, sustainable and inclusive growth, European Commission, Brussels, 2010.

European Sustainable Development Network, 2010, http://www.sd-network.eu (10.12.2010).

Ewing, B., Goldfinger, S., Oursler, A., Reed, A., Moore, D., Wackernagel, M., 2009: The Ecological Footprint Atlas 2009, Global Footprint Network, Oakland.

Gaye, A., 2007: The Human Development Index (HDI), u: Beyond GDP: Measuring progress, true wealth and the well-being of nations, Office for Official Publications of the European Communities, Luxembourg, 264-267.

GDP and beyond: Measuring progress in a changing world, Commission of the European Communities, Brussels, 2009.

Global Footprint Network, 2011, http://www.footprintnetwork.org (25.11.2011).

Human Development Report 2009, United Nations Development Programme, New York, 2009.

Living Planet Report 2006, World Wildlife Fund, Gland, 2006.

Living Planet Report 2008, World Wildlife Fund, Gland, 2008.

Mainstreaming sustainable development into EU policies: 2009 Review of the European Union Strategy for Sustainable Development, Commission of the European Communities, Brussels, 2009.

Moran, D. D., Wackernagel, M., Kitzes, J. A., Goldfinger, S. H., Boutaud, A., 2008: Measuring sustainable development - Nation by nation, Ecological Economics 64, 470-474.

Rees, W. E., 1992: Ecological footprints and appropriated carrying capacity: what urban economics leave out. Environment and Urbanisation 4 (2), 121-130.

Renewed EU Sustainable Development Strategy, Council of the European Union, Brussels, 2006.

Sustainable development in the European Union: 2009 monitoring report of the EU sustainable development strategy, Publications Office of the European Communities, Luxembourg, 2009.

Talberth, J., 2007: Genuine Progress Indicator (GPI), u: Beyond GDP: Measuring progress, true wealth and the well-being of nations, Office for Official Publications of the European Communities, Luxembourg, 270-272.

Thompson, S., Marks, N.,Abdallah, S., Matthews, E., 2009: The Happy Planet Index, u: Beyond GDP: Measuring progress, true wealth and the well-being of nations, Office for Official Publications of the European Communities, Luxembourg, 275-278.

United Nations Development Programme - Human Development Reports Statistics, 2010, http://hdr.undp.org/en/statistics/ (20.12.2010). 
Vintar Mally, K., 2009a: Balancing Socio-economic Development and Environmental Pressures: Mission Impossible? Moravian Geographical Reports 17 (1), 19-29.

Vintar Mally, K., 2009b: Države v razvoju - med okoljevarstvom in razvojnimi težnjami, Znanstvena založba Filozofske fakultete, Ljubljana.

Wackernagel, M., Rees, W. E., 1996: Our Ecological Footprint: Reducing Human Impact on the Earth, New Society Publishers, Philadelphia.

Received (Primljeno): 2010 - 12 - 29

Accepted (Prihvaćeno): 2011 - 11 - 18

Dr. sc. Katja Vintar Mally

Department of Geography

Faculty of Arts

University of Ljubljana

SI-1000 Ljubljana, Aškerčeva 2

katja.vintar@ff.uni-lj.si 